\title{
SALINITY INDUCED ANATOMICAL CHANGES IN MAIZE (ZEA MAYS L. CV. BARI-7)
}

\author{
Sharmin Farhana, PARVEen Rashid AND J.L. KARMOKER \\ Department of Botany, University of Dhaka, Dhaka-1000, Bnagladesh
}

Key words: Salinity, $\mathrm{NaCl}$, Maize, Root, Stem, Anatomical changes

Soil salinity is the main problem limiting plant growth and productivity around the world. This problem is more severe in arid and semi-arid regions. It is estimated that approximately one third of the world's irrigated lands and half of the lands in semi-arid and coastal regions are affected by salinity ${ }^{(1)}$. In Bangladesh, salinity is one of the major natural hazards hampering crop production. Coastal area in Bangladesh constitutes $20 \%$ of the country of which about $53 \%$ are affected by different degrees of salinity(2). Agricultural land use in these areas is very poor. Declining land productivity with shift towards negative nutrient balance is among the main concerns with food security problem in the country. Improving plant resistance to salinity may provide yield stability in subsistence agriculture( ${ }^{(3)}$. Increased salinity induces specific changes at cell, tissue and organ levels. These changes are physiological, morphological and anatomical in nature ${ }^{(4)}$.

Maize has become an important cereal crop in Bangladesh. Its position is 1st among the cereals in terms of yield (maize: $5.30 \mathrm{mt} / \mathrm{ha}$, wheat: $1.60 \mathrm{mt} / \mathrm{ha}$ and rice: $2.52 \mathrm{mt} / \mathrm{ha}$ ) ${ }^{(5)}$ but in terms of area and production, it ranks 3rd just after rice and wheat. Because of more nutritious status, it could be good source of nutrients for under-nourished and malnourished population in Bangladesh. It is now widely used in the poultry farms as feed and also used for human consumption in roasted and fried form. Anatomical changes could compromise plant ability to conduct water and nutrients in high salinity. Thus, the aim of this work was to determine, in the maize seedlings, anatomical alternations produced by salt stress in order to understand salt-tolerance mechanisms.

Seeds of maize (Zea mays L. cv. BARI-7) were collected from Bangladesh Agricultural Research Institute, Joydebpur, Gazipur. Seedlings were raised in earthen pots using sand culture method ${ }^{(6)}$. Each pot $(15 \mathrm{~cm}$ diameter) lined with plastic sheet were filled with dried sand and a hole was made in the plastic sheet corresponding to hole at the bottom of the pot for drainage of water. Sands were soaked with half-strength Hoagland solution in control pot while the sands of salinity treatment were soaked with $200 \mathrm{mM} \mathrm{NaCl}$ solution. Root and stem segments of both control and salinity treatment were taken from 51-day-old seedlings. Stem segments were collected from $1 \mathrm{~cm}$ above the sand surface while roots from $3 \mathrm{~cm}$ below. Free hand sectioning of stem and root was made with the help of a razor blade. The sections were stained in safranin and fast green and mounted over the slide in 10\% glycerin and studied under a compound microscope. Photomicrographs of the sections were taken using a digital camera. 
Structural changes occurred in the vascular system of both stem and root under salinity conditions. Plants under salinity stress showed smaller stem diameter than control. There were reduction in cell sizes and vascular tissues in $\mathrm{NaCl}$-treated plant. In stem, vascular bundles were comparatively large with spherical metaxylem vessels in control plant (Fig. 1A) while in NaCl-treated plant, these became smaller in size (Fig. 1B). Root cross sectional area decreased in NaCl-treated plant compared to control. This was due to reduction in cortical parenchyma as well as in vascular cylinder. In NaCl-treated plants, there were nine metaxylem vessels with smaller cavity in the vascular cylinder (Fig. 1D) compared to 12 prominent and comparatively large metaxylem vessels in the control (Fig. 1C). There were several lacunae in the cortex of the control plant which
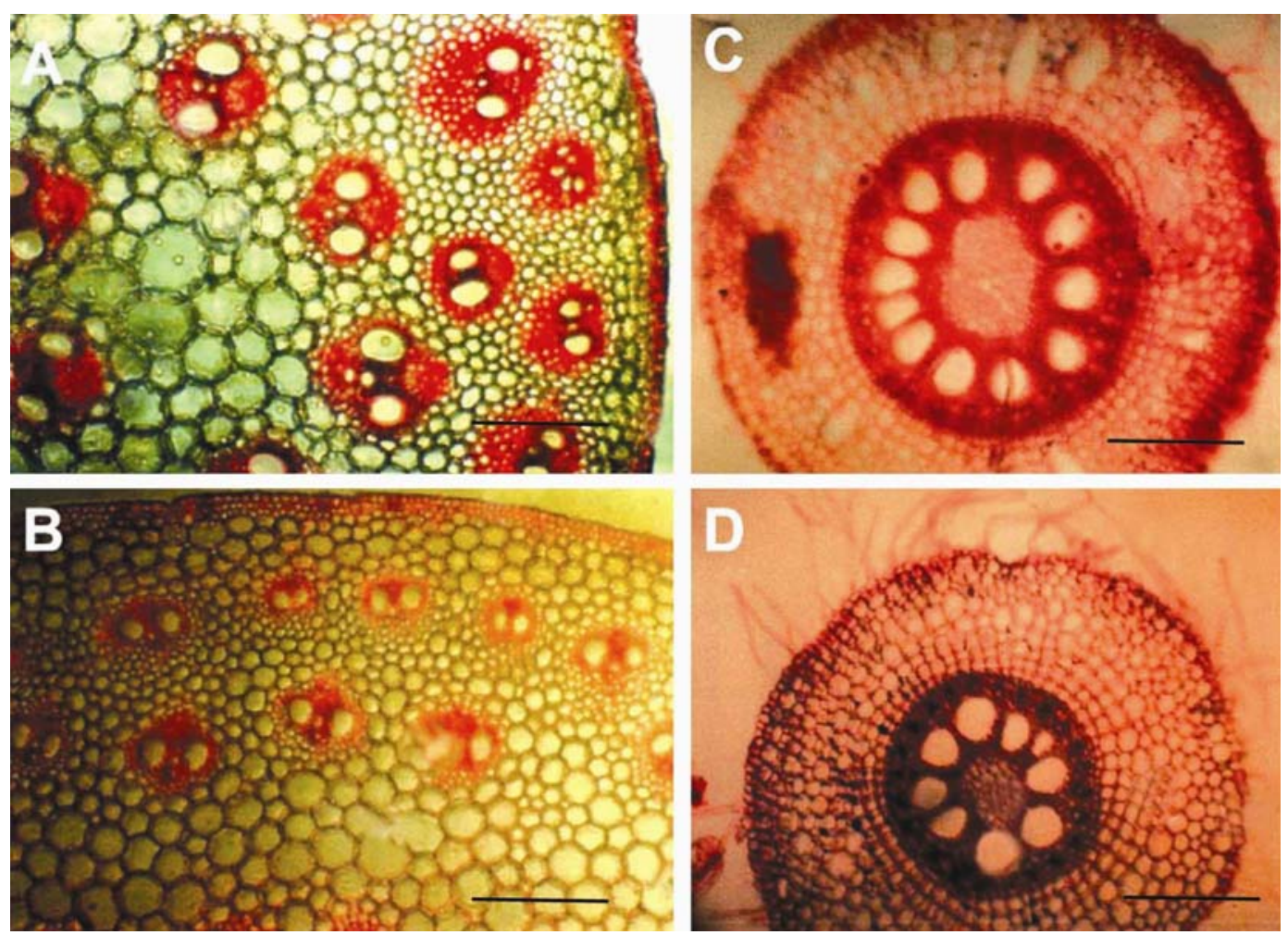

Fig. 1. Cross sections of stem (A \& B) and root (C \& D) of maize. A \& $C=$ control; $B$ \& $D=$ At 200 $\mathrm{mM} \mathrm{NaCl}$. Vascular bundle in stem and cortical parenchyma, vascular cylinder as well as number of metaxylem in root is reduced under salinity. Bar represents $100 \mu \mathrm{m}$.

were absent in the plants grown under salinity. Pith was smaller in salinity treated plants compared to non-treated ones (Figs 1 C \& D). Salinity reduced the number of metaxylem and also reduced the size of the cavity in the root (Fig. D) while the metaxylem in the stem became smaller in size under salinity (Fig. 1B). Reinhardt and Rost found reduced 
length and breadth of metaxylem in cotton seedlings grown under high saline condition $^{(7)}$. Under saline treatment, significant reduction in height and width on cortex and vascular tissue in Atriplex prostata was found by Li-Wen et al.(8). Under salinity stress, decreased number of xylem vessels with smaller size in Carthamus tinctorius was also reported $^{(9)}$. Increase in salinity resulted in a decrease in root diameter of Atriplex semibaccata ${ }^{(10)}$.

The change in diameter and number of xylem structure can affect water transport capacity(11). In salinity, vascular cylinder and cortical parenchyma was reduced, suggesting that a low tolerance of this cultivar to saline environments due to a lower capacity to conduct water and nutrients. So it may be concluded that a reduction in vascular tissue dimensions would limit growth of this species under salt stress conditions.

\section{References}

1. Munns R 2002. Comparative physiology of salt and water stress. Plant Cell Environ. 25: 239250.

2. Hoque SA 2006. Salinity problems and crop production in coastal regions of Bangladesh. Pak. J. Bot. 38: 1359-1365.

3. Flowers TJ and AR Yeo 1995. Breeding for salinity resistance in crop plants: Where next? Aust. J. Plant Physiol. 22: 857-884.

4. Shannon MC 1997. Adaptation of plants to salinity. Adv. Agron. 60: 76-119.

5. BBS 2006. Bangladesh Bureau of Statistics, Agricultural Statistical Year Book of Bangladesh, Dhaka, Bangladesh.

6. Hewitt EJ 1966. Sand and water culture methods used in the study of plant nutrition. Farnham Royal, England: Commonwealth Agricultural Bureau. Technical Communication No. 22 (Revised $2^{\text {nd }}$ ed.) of the Commonwealth Bureau of Horticulture and Plantation Crops, East Malling, Maidstone, Kent. pp. 547.

7. Reinhardt DH and TL Rost 1995. Salinity accelerates endodermal development and induces an exodermis in cotton seedlings roots. Environ. Expt. Bot. 35: 563-574.

8. Li-Wen W, M Showalier and IA Ungar 1997. Effect of salinity on growth, ion content and cell wall chemistry in Atriplex prostata (Chenopodiaceae). Amer. J. Bot. 84: 1247-1255.

9. Gadallah MAA and T Ramadan 1997. Effects of zinc and salinity on growth and anatomical structure of Carthamus tinctorius L. Biol. Plant. (Prague) 39: 411-418.

10. De-Villiers AJ, IV Tichman, MW Van Rooyen and GK Theron 1996. Salinity induced changes in anatomy, stomatal counts and photosynthetic rate of Atriplex semibaccata R. Br. African J. Bot. 62: 270-276.

11. Choat B, MC Ball, JG Luly and JAM Holtum 2005. Hydraulic architecture of deciduous and evergreen dry forest tree species from north-eastern Australia. Trees (Berl) 19: 305-311. 